\title{
The Effect of Fiscal Decentralization and Financial Performance on Economic Growth in District / City of South Sulawesi Province
}

\author{
Muhammad Faisal Arief
}

\begin{abstract}
The purpose of this study is to explain and empirically prove the effect of fiscal decentralization and financial performance on economic growth in the districts / cities of South Sulawesi province. The sample in this study consisted of 3 regions in the form of cities and 21 in the form of districts in the province of South Sulawesi with observational data of 3 (three) years. The data in this study are secondary data obtained from local government financial reports. The analysis technique uses multiple linear regression. The results of this study indicate that fiscal decentralization has a negative and not significant effect on economic growth while financial performance has a significant positive effect on economic growth.
\end{abstract}

Keywords : Economic Growth, Fiscal Decentralization, Financial Performance

\section{INTRODUCTION}

$\mathrm{E}_{\text {conomic growth is one indicator commonly used in }}$ determining the success of development. Economic growth is used as a measure of economic development or progress of a country or region because it is closely related to the economic activities of the community, especially in terms of increasing the production of goods and services. There are several factors that can affect economic growth, including human resources (HR), natural resources (SDA), culture, science and technology (science and technology) and capital resources. Productivity is assessed from the large amount of output of goods and services, will increase Gross Domestic Product (GDP) for the national level and Gross Regional Domestic Product (GRDP) for the regional level [1].

Decentralization is the transfer of authority and responsibility of functions from the central government to regional governments [2], while fiscal decentralization is a process of budget distribution from higher levels of government to lower governments to support government functions or tasks delegated [3]. For Indonesia, fiscal decentralization is one of the mechanisms for transferring funds from the State Budget (APBN) in relation to state financial policies. The country's financial policy is to create fiscal sustainability and provide stimulus to the economic activities of the community. It is hoped that fiscal policy will create an even distribution of financial capacity between regions commensurate with the amount of the authority of

Revised Manuscript Received on October15, 2019

* Correspondence Author

Muhammad Faisal Arief, STIEM Bongaya Makassar, Indonesia Email: hamzahumarfaisal@gmail.com government affairs devolved to autonomous regions.

The realization of effective and efficient financial management, one of which can be measured through the amount of regional income, especially Regional Original Revenue (PAD). PAD received by the government will then be used in government spending which is expected to influence economic growth in an area [4]. An area is considered successful in managing regional finances, if the regional financial performance of the regional government is categorized as good. Regional financial management is carried out economically, efficiently, and effectively or meets the principles of value for money and participation, transparency, accountability and justice that can drive economic growth [5].

Based on research conducted by [6] states that fiscal decentralization has a significant effect on economic growth and financial performance has a significant effect on economic growth. This is in line with what has been investigated by [7] who concluded that fiscal decentralization has an effect on economic growth, which means that efforts to increase the role of local governments in the development process in Bali's provincial areas are already underway. effectively providing a stimulus for economic growth. Research [6] is also in line with research conducted by [5] which concludes that financial performance has a significant indirect effect on economic growth in Regencies / Cities in Central Java.

\section{A. Economic growth}

According to Murni [8] the definition of economic growth is a condition in which the development of Gross National Product (GNP) which reflects the growth of per capita output and the increase in people's living standards. Economic growth can be interpreted as a process of changing a country's economic conditions on an ongoing basis towards better conditions for a certain period.

Gross National Product (GNP) is the total value of income from all goods and services produced by citizens of a country, including those who work abroad at a certain period (usually annual). GNI is a basic measure of economic activity. In addition to the size of the GNP, there is what is known as the Gross Domestic Product (GDP) which is defined as the total income generated by all people both citizens themselves and foreign nationals from all goods and services in a country. 


\section{The Effect of Fiscal Decentralization and Financial Performance on Economic Growth in District / City of South Sulawesi Province}

GDP measures the value of all goods and services produced in the country (domestic) without differentiating ownership / citizenship in a certain period. Citizens who work in other countries, their income is not included in the calculation of GDP.

The indicator uses the data of the Gross Regional Domestic Product (GRDP) to measure the economic growth rate of the regencies / cities of South Sulawesi province in this study [9]. With the following formula:

Economic Growth $=($ PDRB_t - PDRB_ $((t-1))) /$ PDRB_ $(\mathrm{t}-1) \times 100 \%$ Note: GRDP $=$ GRDP of the year to be calculated GRDP $(\mathrm{t}-1)=$ GRDP of the previous year

\section{B. Fiscal Decentralization}

Law Number 23 of 2014 concerning Regional Government (the Local Government Law) explains the meaning of decentralization stating that "Decentralization is the transfer of governmental authority by the Government to autonomous regions to regulate and administer government affairs within the Unitary State of the Republic of Indonesia" system. According to World Bank 1997 in [10], there are three mechanisms of the impact of fiscal decentralization on economic growth. The first argument says that fiscal decentralization will increase economic efficiency in the government expenditure sector, so this dynamic effect will drive economic growth. The second argument, that decentralization will cause macroeconomic instability, so that it will disrupt economic growth.

In this study will use the measurement of fiscal decentralization through the expenditure approach (expenditure), namely the ratio of district / city government expenditure originating from regional own-source revenue (PAD) to the total realization of regional expenditure (in percent units) which includes and received from the central government and provinces in the form of balances and other transfer funds. The measurement illustrates the independence or financial capacity of the region in financing the administration of its government. This approach is used because the expenditure side is far greater in driving economic growth than through the revenue side. This expenditure approach is similar to that used by $[6,11,12$, 13,14]. The expenditure approach to research This is calculated by the formula:

Fiscal Decentralization $=(\mathrm{PAD}+$ Tax and Non-Tax Profit Sharing $) /$

(Realization of Total Regency / City Expenditures) $\times 100 \%$

\section{Financial performance}

According to Perpres No. 29 of 2014, performance is the output / results of activities / programs that have been or want to be achieved in connection with the use of the budget with measured quantity and quality. Sularso and Restianto stated that performance is an achievement of what was planned, both by individuals and organizations [5]. Meanwhile, according to Solihin, performance is the achievement of a person, team or work unit in carrying out a task compared to the targets targeted at him [15]. Performance measurement serves to assess the success or failure of an organization, program or activity.

According to Syamsi (1986) in [16], the financial

performance of a regional government is the ability of a region to explore and manage local financial resources in meeting their needs to support the running of the government system, service to the community and development in the region by not totally relying on the central government and having the discretion in using funds for the benefit of the local community in the natural limits determined by laws and regulations. Sularso argues that in measuring the financial performance of local government organizations is done by using the degree of decentralization ratio, financial dependency ratio, regional financial independence ratio, effectiveness ratio, the degree of contribution of BUMD, efficiency ratio, and alignment ratio shopping [5].

The higher the ratio of independence, the level of regional dependence on external parties (especially the central and provincial governments) is getting lower and vice versa [17].

The financial independence ratio is calculated by the formula:

Independence Ratio $=($ Local Revenue $) /($ Balance Funds + Regional Loans $) \times 100 \%$

Thus, based on the above description the hypothesisof this research can be formulated as follows:

H1 : Transformational leadership style has significant impact on the development of the creativity of workers

\section{MATH}

In this study defined as the population are all districts / cities in South Sulawesi Province consisting of 21 districts and 3 cities. The object of this research is the Gross Regional Domestic Product Data and the Realization Report of the Revenue and Expenditure Budget (APBD) of the Regency / City in South Sulawesi Province within a period of 3 years namely 2014-2016 so that the total population sampled is 72 data.

Regression Model:

$\mathrm{Y}=\alpha+\beta 1 \mathrm{X} 1+\beta 2 \mathrm{X} 2+\beta 3 \mathrm{X} 3+\beta \mathrm{nXn}+\mathrm{e}$

Information :

$\mathrm{Y}=$ Economic Growth

$\alpha=$ Constants ( $\mathrm{Y}$ values if $\mathrm{X} 1, \mathrm{X} 2, \ldots, \mathrm{Xn}=0$ )

$\beta 3, \beta 1, \beta 2, \beta n=$ Regression Coefficients for $X 1, X 2$, and $X n$

$\mathrm{X} 1=$ Fiscal Decentralization

$\mathrm{X} 2=$ Financial Performance

$\mathrm{Xn}=$ Other factors

$\mathrm{e}=$ Residual / Error

\section{RESULTS AND DISCUSSION}

The research approach used is a quantitative method with descriptive statistical analysis using SPSS statistical applications. This type of data uses secondary data taken from the financial statements of the South Sulawesi provincial government. This analysis tool is used to find the effect of fiscal decentralization on economic growth and the effect of financial performance on economic growth in the province of South Sulawesi.

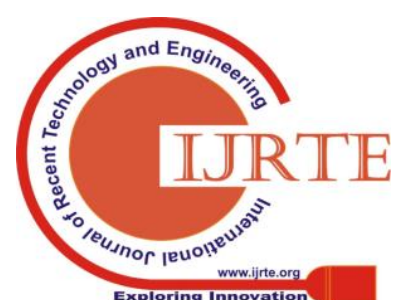


Determination Coefficient Test (R2)

The results of the coefficient of determination can be seen from the following table:

\begin{tabular}{|c|c|c|c|c|c|}
\hline \multirow[b]{2}{*}{ Model } & \multicolumn{2}{|c|}{$95,0 \%$ Confidence Interval for B } & \multicolumn{3}{|c|}{ Correlations } \\
\hline & Lower Bound & Upper Bound & Zero-order & Partial & Part \\
\hline 1. (Constant) & 6,612 & 8,782 & & & \\
\hline Decentralization &,- 228 &, 129 & ,020 &,- 066 &,- 066 \\
\hline Financial performance &,- 064 &, 124 & ,043 & ,076 & ,076 \\
\hline
\end{tabular}

It can be seen that fiscal decentralization has a correlation coefficient of 0.020 and financial performance has a correlation coefficient of 0.043 . This means that fiscal decentralization has an influence contribution of $2 \%$ and financial performance has an influence contribution of $4.3 \%$ to economic growth. while the remaining $0.937(93 \%)$ is influenced / explained by other variables not proposed in this study.

F Test (Simultaneous Test)

\begin{tabular}{|l|r|r|r|r|r|}
\hline & Sum of Squares & Df & Mean Square & F & \multicolumn{1}{|c|}{ Sig } \\
\hline 1 Regression &, 794 & 2 &, 397 &, 216 &, $807^{\mathrm{b}}$ \\
Residual & 127,078 & 69 & 1,842 & & \\
Total & 127,873 & 71 & & & \\
\hline
\end{tabular}

Anova table shows that the calculated $\mathrm{F}$ value of 0.216 and the $\mathrm{F}$ table at a $95 \%$ confidence level and the degree of freedom $(2: 69)$ obtained from $(\mathrm{k}: \mathrm{nk}-1)(2: 72-2-1=69)$ then the $\mathrm{F}$ table value is obtained $=3.129644$.

Therefore, F count 0.216 is smaller than F table 3.129644 then with a degree of error of $5 \%(\alpha=0.05) \mathrm{H} 0$ is accepted and $\mathrm{Ha}$ is rejected. This means that with a $95 \%$ confidence level it can be said that Fiscal Decentralization and Financial Performance together have insignificant effect on Economic Growth

T test (Partial Test)

\begin{tabular}{|c|c|c|c|c|c|c|c|c|c|c|}
\hline \multirow[b]{2}{*}{ Model } & \multicolumn{2}{|c|}{$\begin{array}{l}\text { Unstandardize } \\
\text { d Coefficients }\end{array}$} & \multirow[t]{2}{*}{$\begin{array}{l}\text { Standardized } \\
\text { Coefficients }\end{array}$} & \multirow[b]{2}{*}{$\mathrm{t}$} & \multirow[b]{2}{*}{ Sig } & \multicolumn{2}{|c|}{$\begin{array}{c}95,0 \% \\
\text { Confidence } \\
\text { Interval for B }\end{array}$} & \multicolumn{3}{|c|}{ Correlations } \\
\hline & $\mathrm{B}$ & $\begin{array}{l}\text { Std. } \\
\text { Error }\end{array}$ & & & & $\begin{array}{l}\text { Lowe } \\
\text { r } \\
\text { Boun } \\
\text { d }\end{array}$ & $\begin{array}{l}\text { Upper } \\
\text { Boun } \\
\text { d }\end{array}$ & $\begin{array}{l}\text { Zero- } \\
\text { order }\end{array}$ & $\begin{array}{l}\text { Partia } \\
1\end{array}$ & Part \\
\hline 1 (Constant) & 7,697 &, 544 & & 14,151 & ,000 & 6,612 & 8,782 & & & \\
\hline Fiscal &,- 049 & ,089 &,- 202 &,- 549 & ,585 &,- 228 & ,129 & ,020 & $-0,66$ &,- 066 \\
\hline $\begin{array}{l}\text { Decentralization } \\
\text { Financial } \\
\text { performance }\end{array}$ &, 030 & ,047 & ,235 & ,636 &, 527 &,- 064 & $-0,64$ &, 043 & ,076 & ,076 \\
\hline
\end{tabular}

The value of the table with $\alpha=0.05$ and degree of freedom $=72-1-1=70$ for testing two parties is 1.99437 . Therefore tcount for the coefficient variable fiscal decentralization 0.549 (negative sign ignored / adjust criteria) is smaller than table $1.99437(0.549<1.9934)$, then the error rate of $5 \% \mathrm{H} 0$ is accepted and $\mathrm{H} 1$ is rejected. Thus at a $95 \%$ confidence level it can be said that fiscal decentralization has a negative and in significant effect on economic growth. While the value of the table with $\alpha=0.05$ and free degrees $=$ $72-1-1=70$ for testing two parties is 1.99437 . Therefore, tcount for the coefficient of financial performance variable is 0.636 smaller than $\mathrm{t}$ table 1.99437 (0.636> 1.9934), then the error rate of $5 \% \mathrm{H} 0$ is accepted and $\mathrm{H} 2$ is rejected. Thus at $95 \%$ confidence level it can be said that financial performance has a positive and not significant effect on economic growth. 


\section{The Effect of Fiscal Decentralization and Financial Performance on Economic Growth in District / City of South Sulawesi Province}

\section{FINDINGS}

Effects of Fiscal Decentralization on Economic Growth

The total PAD and Total DBH \& DBHBP are too low when compared to the total regional government expenditure. In terms of PAD, it illustrates the weakness of local governments in absorbing the potentials in their respective regions as well as the lack of creativity of local governments to create and obtain high sources of local revenue. PAD obtained is not enough to cover local government expenditure so it must rely on assistance from the central government in the form of regional balance funds and loans.

Because fiscal decentralization increases incentives for regional governments to behave opportunistically by trying to shift the burden of regional spending to the center as a whole. This will eventually lead to coordination between fiscal and monetary policies facing challenges to national economic stability. Excessive spending is very high illustrates the ability of local governments in spending efficiency is still not good. This means that local governments have not been successful in implementing fiscal decentralization policies in the field in the efficiency of the public sector in order to encourage economic growth.

This indicates the correctness of Remy Prud'homme's opinion in [18] which says that fiscal decentralization is considered to cause fiscal waste by local governments. Because fiscal decentralization increases incentives for local governments to behave opportunistically by trying to shift the burden of regional spending to the center as a whole.

However, based on the discussion of theoretical reviews and previous research, the results of this study support the findings of previous studies $[19,20,10,21,22]$ who concluded that there was a negative influence of fiscal decentralization on economic growth.

\section{Effect of Financial Performance on Economic Growth}

The value of Local Own Revenue (PAD) is very low when compared to the value of the balance funds plus regional loan funds. This means that the financial performance of local governments in the Regencies / Cities of South Sulawesi Province is still very weak or not good in absorbing local revenue. High balance funds and loan funds illustrate that the financial independence of the regional government of the Regency / City of South Sulawesi Province is not good or the dependence on external parties is very high in financing their government spending. Based on these explanations, the researcher can understand if the financial performance of the district / city government in South Sulawesi Province does not significantly influence economic growth.

The original income of the regency / city area in South Sulawesi Province is too low and results in the effect of financial performance on economic growth that is not so significant or only has a pseudo effect. In addition, the value of balancing funds and borrowed funds is so high that there is no strong influence of the performance finance to economic growth. This can be seen from the data of the region's original income, balance funds and regional loans.

The results of this study support the findings of previous studies $[23,24]$ which state that financial performance using regional financial independence ratios has no significant effect on economic growth.

\section{CONCLUSION}

Based on the research results, the following conclusions can be drawn:

a. Fiscal decentralization has a negative and not significant effect on economic growth.

b. Financial performance has a positive and not significant effect on economic growth.

\section{REFERENCES}

1. Seran, Sirilius. (2016) .Education \& Economic Growth versus Population Poverty (Case in East Nusa Tenggara Province). Yogyakarta: Deepublish.

2. Karianga, Hendra. (2017). Disorganization of Regional Financial Management in the Era of Regional Autonomy. Jakarta: Kencana.

3. Suwandi (2015) Fiscal decentralization and its impact on economic growth, employment, poverty, and welfare in Papua's city district

4. Arsa, I Ketut and Setiawina N. Djinar. (2015) Influence of financial performance on the allocation of capital expenditure and economic growth of regency / city governments in the province of Bali from 2006 to 2013. Journal of the economic study bulletin.

5. Sularso, Havid and Yanuar E. Resianto. (2011). The Effect of Financial Performance on Capital Expenditure Allocation and Economic Growth in Regencies / Cities in Central Java. Accounting Research Media. Vol. 1, No. 2. August 2011.

6. Muryaman, Sang Made and Made Sukarsa. (2016). The Effect of Fiscal Decentralization, Fiscal Stress, and Financial Performance on Economic Growth in the District / City of Bali Province. E-Journal of Economics and Business, Udayana University. ISSN: 2337-3067.

7. Yudha, Dewa Made AdiKesuma, Made GedeWirakusuma and Ni KetutRasmini. (2016). Effects of Fiscal Decentralization on Economic Growth by moderating Accountability in Financial Reporting. E-Journal of Economics and Business, Udayana

8. Murni, Asfia (2009) Macro Economics. Bandung. Refika Aditama

9. Hasyim, Ali Ibrahim. (2017). Macro economics. Jakarta: Prenada Media

10. Saputra Bambang (2013) the effect of fiscal decentralization on economic growth and public welfare. borneo journal administrator. Vol 9 No 1

11. Kresnandra, AgunggNgurahAgung's Child. (2016). Effect of Fiscal Decentralization on Regional Economic Growth with Private Balance Funds and Investment as moderating variables. Business and Management Journal. Vol. 3, No. 2. June 2016.

12. Kharisma, Bayu. (2013). Fiscal Decentralization and Economic Growth: Before and After the Era of Fiscal Decentralization in Indonesia. Journal of Economics and Development Studies. Vol. 14, No. October 2nd, 2013.

13. Khalid, Idham. (2015). The Effect of Fiscal Decentralization on Economic Growth in South Sulawesi.

14. Apriesa, LintantiaFajar and Miyasto. (2013). Effects of Fiscal Decentralization on Regional Economic Growth and Income Inequality (Case Study: District / City in Central Java). Diponegoro Journal of Economics. Vol. 2, No. 1

15. Solihin Ismail (2009) introduction to management. Jakarta. Erlangga

16. Soedarsa, H. Gunawan and Avrina T. D. Putri (2014) analysis of the performance of regency municipalities in Lampung Province accounting and financial journals. Vol 5 No. 2

17. Halim, Abdul, et al. (2008). Public Sector Accounting for Regional Financial Accounting. Issue 4. SalembaEmpat: Jakarta.

18. Rasbin (2016) Fiscal decentralization of macroeconomic stability; case study in Indonesia. Research Center for the expertise of the Indonesian Parliament

19. Pepinsky, Thomas B and Maria M Wiharja (2009) Decentralization and Economic Performance in Indonesia Centre for Strategis and International Studies.

20. Andres Rodriques., Anne Kroijer (2009) Fiscal Decentralization and Economic Growth in Central and Eastern Europe. London School of Economic.

21. Philip Abachi Termehen and Salamutu Isah (2012) An Analysis of the Effect of Fiscal Decentralization on Economic Growth in Nigeria International Journal of Humanities and Social Science. Vol 2 No 8. 
22. Hidayat, Muhammad Noor Sandi. (2016). Analysis of the impact of fiscal decentralization on regional economic growth in East Java

23. Siregar. H. Aroza (2016) Analysis of the effect of financial performance on the economic growth of Riau Province with capital expenditure as a moderating variable. University of Riau Journal

24. Sukarni Ni Wayan and Budiasih IN (2016) The allocation of capital expenditure as a moderating effect of financial performance on the economic growth of city districts in the province of Bali. Uayana University E-Journal of Economics and Business

\section{AUTHORS PROFILE}

Muhammad Faisal Arief is from STIEM Bongaya Makassar, Indonesia 